\title{
Anthropogenic Threats and Conservation Needs of Blue Whales, Balaenoptera musculus indica, around Sri Lanka
}

\author{
A. de Vos, ${ }^{1,2}$ R. L. Brownell Jr., ${ }^{3}$ B. Tershy, ${ }^{2}$ and D. Croll ${ }^{2}$ \\ ${ }^{1}$ The Sri Lankan Blue Whale Project, 131 WAD Ramanayake Mawatha, Colombo 2, Sri Lanka \\ ${ }^{2}$ Department of Ecology and Evolutionary Biology, Center for Ocean Health, University of California Santa Cruz, \\ 100 Shaffer Road, Santa Cruz, CA 95060, USA \\ ${ }^{3}$ Southwest Fisheries Science Center, 34500 Highway 1, Monterey, CA 93940, USA
}

Correspondence should be addressed to A. de Vos; ashadevos@gmail.com

Received 1 February 2016; Accepted 3 May 2016

Academic Editor: Ricardo Serrão Santos

Copyright (C) 2016 A. de Vos et al. This is an open access article distributed under the Creative Commons Attribution License, which permits unrestricted use, distribution, and reproduction in any medium, provided the original work is properly cited.

\begin{abstract}
Blue whales in the Northern Indian Ocean are a morphologically and acoustically distinct population restricted to these waters. Off Sri Lanka a portion of the population concentrates near shore where they are exposed to a range of anthropogenic threats. We review available data to determine anthropogenic threats/stressors faced by this population and assign subjective rankings for the population-level severity of each threat/stressor based on severity, scope, and immediacy. With the cessation of direct illegal catches on this population in the late 1960s, we ranked ship strike as the most important population-level threat. Incidental catch, which includes entanglement and bycatch, is also important as it can result in death. Other less important stressors that may negatively impact this population include threats resulting from oil and gas development and pollution. However, some stressors can have a long-term cumulative impact that is difficult to assess. The most important research needed for the conservation of these whales is to obtain an estimate of the size of the population using photo-identification methods.
\end{abstract}

\section{Introduction}

The pygmy blue whale complex (Balaenoptera musculus subspp.), which includes the Northern Indian Ocean (NIO) population (B. $m$. indica; described below), occurs primarily outside the central gyre of the Indian Ocean including the African northeastern coast, various islands in the Arabian Sea, and the western Australian coast to the Banda Sea, along the Australian southeastern coast to New Zealand [1], around Diego Garcia [2], the western coast of South America (Peru and Chile), south of Madagascar, and around most of the Sub-Antarctic Islands (Prince Edward, Kerguelen, Crozet, Heard, and Amsterdam) during the austral summer [3] (Figure 1). Various populations are known to associate closely with localized high productivity systems in areas such as the Perth Canyon, Australia [4]. At present, all Indian Ocean pygmy blue whale populations are collectively listed as "Data Deficient" by the IUCN Red List of Threatened Species [5]. This listing includes the NIO subspecies of blue whales which needs to be assessed independently for the Red List.
The pygmy blue whale population in the NIO is poorly studied, but it is recognised as a distinct subspecies, $\mathrm{Bal}$ aenoptera musculus indica $[6,7]$. They are approximately $5 \mathrm{~m}$ shorter at maturity than their Antarctic counterparts, breed six months out of phase with the pygmy blue whales in the southern Indian Ocean B. m. brevicauda [8], and have a unique acoustic call $[9,10]$. Unlike other blue whale populations, the NIO population does not migrate annually to cooler waters to feed but remains in warm, tropical waters year-round $[11,12]$. This subspecies is rare in the Bay of Bengal apart from the southwestern most extent, around the east coast of Sri Lanka. Year-round sightings, photo-identification records, and stranding data suggest that at least a portion of this population remains resident within Sri Lankan waters [11-15]. A number of regions where these NIO pygmy blue whales aggregate have been identified, including Somalia [16], the Seychelles [8], the Maldives [17, 18], Diego Garcia [2], and Sri Lanka [19], one that is occupied almost yearround as suggested by sightings, strandings, and acoustic data. 


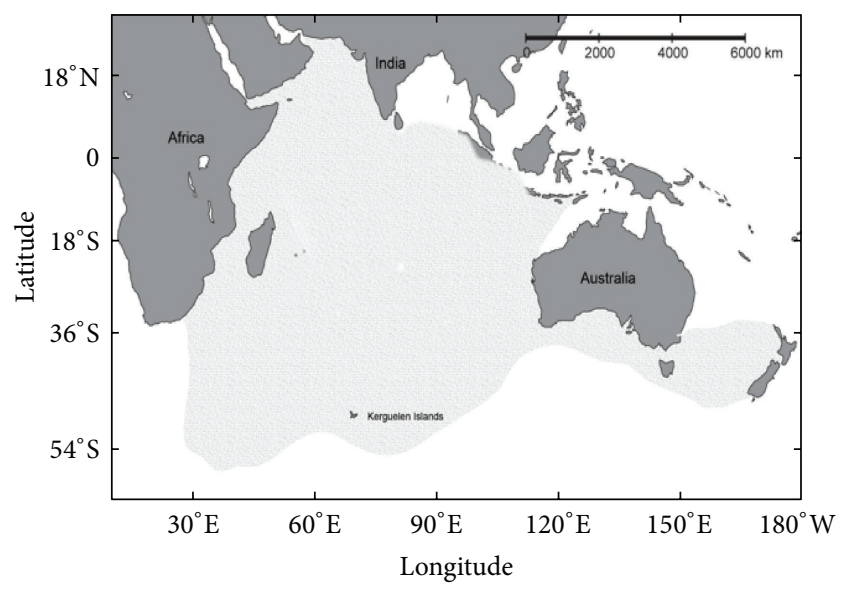

FIGURE 1: Distribution of pygmy blue whale population in the Indian Ocean (redrawn from [1] and [2]).

Blue whales have been documented from around Sri Lanka for at least 130 years with the earliest confirmed stranding in 1885 [20] and all records are assumed to be B. m. indica. In Sri Lankan coastal waters, these whales are known from two major areas: off Trincomalee in the northeast and off the southern coast. Mother-calf pairs have been observed in both areas ([11]; de Vos unpublished observations), and one blue whale birth has been observed in the Trincomalee Harbour [21], indicating that it may be a calving area. In addition, groups of whales have been observed engaging in mating activity as described by Sears et al. ([22]; de Vos unpublished observation). Perhaps most importantly they form aggregations and are observed feeding [19] and defecating off the south coast of Sri Lanka during the Northeast Monsoon (December to March) [12]. These observations are consistent with those recorded for foraging whales in other important blue whale areas $[23,24]$, supporting the hypothesis that this is an important foraging area for Northern Indian Ocean pygmy blue whales [19].

Despite years of commercial exploitation, blue whale populations are still found in all major oceans, but the current size of most populations is estimated to be a fraction of preexploitation levels [14, 25]. By 1966 the International Whaling Commission (IWC) had banned the killing of blue whales worldwide. Despite this ban, illegal Soviet pelagic whaling continued in the 1960s and early 1970s, resulting in an estimated take of 11,719 pygmy blue whales in the Southern Hemisphere and NIO [26, 27].

Little research has focused on the current population status and ecology of NIO pygmy blue whales. Their numbers are thought to be severely reduced due to illegal hunting by Soviet factory ships in transit to whaling operations in the Southern Ocean between 1963/64 and 1966/67 [28]. During these four seasons a total of 1,294 individuals were taken in the waters off the Seychelles, the Maldives, in the Gulf of Aden, and off the west coast of southern India and Sri Lanka [28]. Due to a lack of preexploitation and current population estimates, the impact of the removal of this number of individuals from the population is unclear.
However, given the sizeable decrease in catch sizes following the 1964/65 season (during which 986 individuals were taken) [28], it is likely that population size was quickly reduced to a lower level. There has been no commercial or artisanal direct harvest since 1967. Before the Soviet catches in the 1960s, they were not hunted except for occasional individuals taken in the late 19th century [29].

Little is known about sources of natural mortality for any blue whale population [30]. Similar to many blue whale populations, those around Sri Lanka are frequently sighted in nearshore waters that support high levels of human activity in the form of shipping, fishing, and whale-watching. The restriction of this subspecies in the western Northern Indian Ocean along with its potentially small population size and high density in nearshore waters makes it vulnerable to human activities. Ilangakoon [31] reviewed threats to Sri Lankan blue whales, but we have updated that review here to provide more detail on the major threats, a subjective ranking of these threats, and discuss future research and conservation needs.

\section{Methods}

For this review we conducted a systematic review of both the primary and secondary literature, which consisted of peerreviewed publications and reports, and collated unpublished field data.

\section{Threats}

Coastal areas with high productivity can support large, diverse populations of marine mammals but also experience the highest levels of human impact [32]. Davidson et al. [32] identified the coastal Indo-Pacific as a region with potentially high anthropogenic threat for many marine mammal populations. Another study assessing human impact on marine ecosystems around the world identified the waters off Sri Lanka, particularly the continental shelf and slope, as an area experiencing among the highest predicted cumulative anthropogenic impact globally (based on an estimation of ecosystem-specific differences in impact of 17 anthropogenic drivers of ecological change broadly categorized as pollution, fishing, and climate change) [33].

Factors that increase extinction risk in vertebrates include large body size, longevity, and restricted distribution [34]. NIO blue whales are large and have relatively slow life histories (although not when corrected for body size) and restricted range. Thus, the population of pygmy blue whales around Sri Lanka is particularly threatened due to the combination of relatively slow life histories, restricted ranges, potentially small population size, and high cumulative human impacts when compared to other Indian Ocean pygmy blue whale populations.

3.1. Incidental Catch. The incidental catch of marine megafauna, including marine mammals, in fishing gear poses a significant threat to many species [35]. Entanglement in fishing gear such as gill nets, long lines, and discarded trawl nets may directly lead to mortality through drowning 
or indirectly via impaired locomotion or foraging efficiency that is due to injury/incapacitation. Much of this mortality is not recorded as bycatch in fisheries statistics ("cryptic bycatch") because animals caught in fishing gear swim away injured or subsequently die, with or without gear attached [36]. Further, global cetacean bycatch rates are typically under-reported and therefore underestimated [37]. As a result, the overall impact of entanglement is unknown and likely varies between populations depending on their demography, population size, and bycatch rate.

Despite their large size, blue whales are susceptible to gill net entanglement [30]. While gill net-related mortality is only reported from three incidences in the Gulf of St. Lawrence between 1979 and 2002 [38], it is assumed that incidental entanglement occurs elsewhere [39]. Indeed, Reeves et al. [36] estimated that over the past two decades $64 \%$ of baleen whale bycatch was caused by entanglement in gillnets. Thirteen of the 14 recognised mysticete species were bycaught in gillnets between 1990 and 2011. During this same period 28 out of 90 countries surveyed recorded gill net entanglements of mysticetes [36]. Pelagic drift nets, which are generally set near the surface in deeper waters, have been recognised as a potential threat to blue whales. For example, a drift gillnet fishery for swordfish and sharks off California and Baja California, Mexico, has been identified as a potential threat to blue whales off Mexico/California [40]. Drift gill nets are also the most commonly used fishing gear in Sri Lanka, followed by long lines [41].

Records of baleen whale mortality due to entanglement in fishing gear off Sri Lanka are limited, with only two published cases. The first was a $12.04 \mathrm{~m}$ humpback whale which stranded on 22 January 1981 at Chilaw after becoming entangled in fishing gear [42]. The second case was a $7.5 \mathrm{~m}$ Bryde's whale, misidentified as a fin whale, taken as bycatch in a gill net fishery and landed at Negombo on 4 July 1985 $[43,44]$. In addition, unpublished records of entanglement include a pygmy blue whale observed trailing longline with the hooks attached to its back and dorsal area in February 2011 off Mirissa, southern Sri Lanka (de Vos, unpublished observation), and a second pygmy blue observed trailing fishing gear off Mirissa in January 2013 by Tony Wu (pers. comm.) (Figure 2). The net was wrapped through its mouth, along the sides of its body and wound around its tail. This individual was noticeably thin and unable to dive. The scarring patterns around its tail stalk indicated that it had been attached to this gear for an extended period. We consider this case a serious injury that will likely result in death of the whale.

3.2. Ship Strikes. Ship strikes are a well-documented cause of mortality for many species of baleen whales including blue, fin, sei (B. borealis), Bryde's, right (Eubalaena glacialis), and gray whales (Eschrichtius robustus) [45-48].

Observations of stranded and injured baleen whales in the United States and similar observations off Panama have led to a consensus that ship strikes are an important source of mortality, leading to management action that factors whale distributions in locating shipping lanes and mandatory reduction in speeds to minimize incidental mortality for

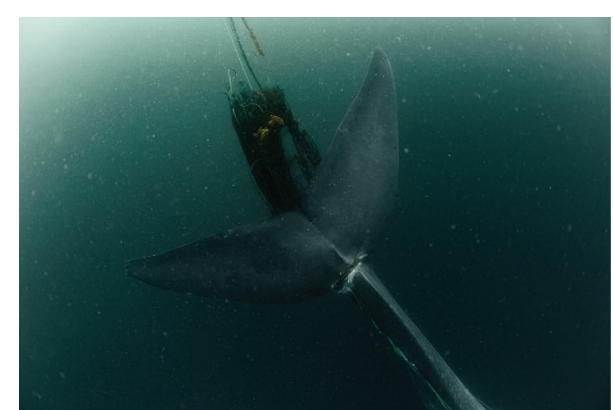

Figure 2: Blue whale entangled in large mesh drift gillnet off Mirissa, Sri Lanka, in February 2011 (photo credit: Tony Wu).

a number of baleen whale species $[47,49,50]$. Risk of collision and likelihood that it will result in severe or lethal injury was shown to increase when vessels exceeded 10-14 knots $[45,51]$. Given that ship strike is a particularly serious threat to the recovery of the endangered Northern Atlantic right whale [52], a ship strike reduction rule was adopted in 2008 that requires ships exceeding 65 feet to travel at 10 knots or less at prescribed times and locations along the east coast of USA to reduce collisions with this species. The implementation of this regulation was accompanied by an outreach campaign and system of citations and fines as a means to increase compliance rates [53]. As a result of these regulations, no fatalities from ship strikes have since been reported $[54,55]$.

Blue whales along the California coast are particularly susceptible to ship strikes when prey concentrates in the vicinity of commercial shipping lanes [47]. Feeding whales are deemed more vulnerable to ship strike as they may be less responsive to approaching ships [45]. In commercial shipping lanes off southern California, McKenna et al. [56] tracked blue whale movements in the presence of ships. They documented a short-term shallow dive response in the path of oncoming ships in 55\% of the encounters but found no evidence for lateral avoidance. They speculate that blue whales do not display avoidance behaviors because they have never evolved defensive behavioral responses to potential predators due to their large size, which in turn makes them vulnerable to ship strike.

Typically, krill patches are dense and deep during daylight hours to avoid predation, while they aggregate at the surface to facilitate feeding on phytoplankton located closer to the sea surface at night [57]. Goldbogen et al. [58] showed that blue whales in the North Pacific Ocean ceased foraging at night either because they had reached a foraging threshold related to critical prey density or because they cannot visually locate krill without downwelling light. Therefore, blue whales are likely more susceptible to ship strike during these hours as a result of prolonged surface times and reduced avoidance behaviors.

Over $90 \%$ of the whale ship strikes $(n=53)$ examined by Laist et al. [45] occurred either on the continental shelf or shelf slope with most lethal or severe injuries involving ships travelling 14 knots or faster. Laist et al. [45] report three bowpinned blue whales between 1980 and 1998 off Mexico, in the 


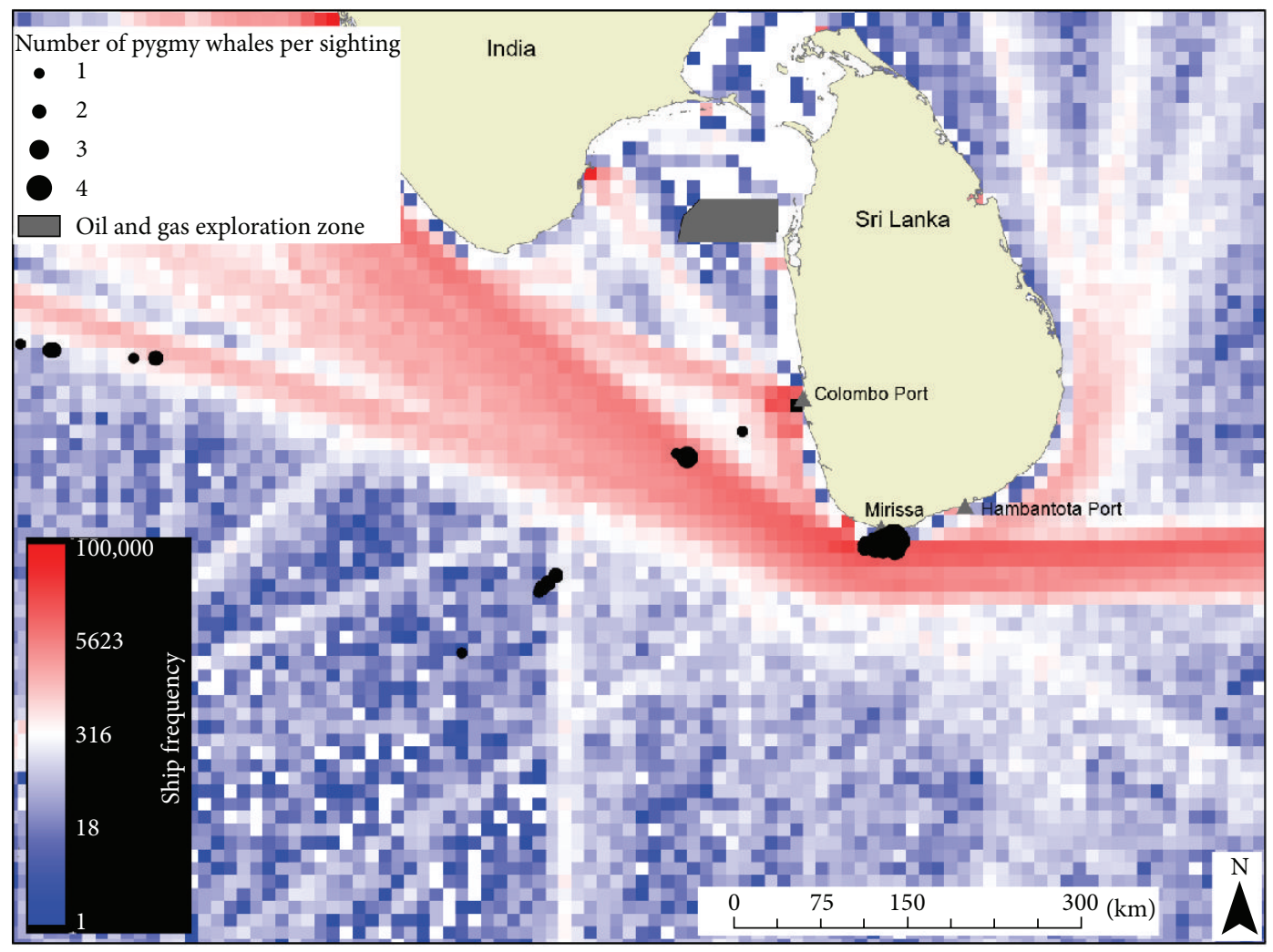

FIGURE 3: Map showing ship traffic frequency (red-blue), oil and gas exploration zone SL2007-01-01 which was the first to be explored in Sri Lankan waters in 2011 (gray box), pygmy blue whale sightings (black dots), and areas of relevance around Sri Lanka. Data sources include Potemra [59], National Aquatic Resources Research and Development Agency [60], Ballance and Pitman [61], de Vos et al. [19], and de Vos, unpublished data.

North Atlantic and the North Pacific. In all three cases the ship's crew were unaware that they had hit a whale. Several photo-identified whales off California had large gashes on their dorsal body surfaces typical of vessel collisions [62]. In the Gulf of St. Lawrence, $16 \%$ of living, photo-identified blue whales bore scars likely caused by collisions with vessels [38]. Recently, a blue whale was also struck and killed by a ship that docked in Puerto Montt, Chile [63].

An emerging strategy to reduce blue whale death by ship strike has been to move shipping lanes and reduce ship speeds in the vicinity of foraging blue whales. Irvine et al. [64] found that individual blue whale home ranges and core areas of use off California corresponded with areas of high productivity that overlapped with commercial shipping lanes. They recommended a southward shift of shipping lanes in the high-use area of the Santa Barbara Channel, particularly between July and October. In addition, they advocated the closure of the northern shipping lane leading to and from the port of San Francisco Bay between August and November or the creation of an east-west lane extending to the 2,000 m isobath before bifurcating in order to reduce the likelihood of blue whale ship strike. These recommendations highlight the need for context-specific interventions in other regions.

As the main east-west route through the NIO, the southern coast of Sri Lanka supports one of the busiest shipping lanes in the world. Over 5,000 cargo ships greater than 10,000
GT transit this area every year; one cargo ship every two hours ([65]; Figure 3). Based on satellite-derived commercial shipping density data, it has been determined that southern Sri Lanka is in the top $0.2 \%$ globally in terms of ship traffic [66]. This is approximately double the shipping traffic off of California's Santa Barbara Channel where measures are currently being taken to mitigate the risk of ship strikes with the Californian population of blue whales $[67,68]$. The population is estimated at 2,100 individuals and is believed to have recovered from commercial whaling during the 20th century [69]. Recent evidence suggests that ship strikes are not an imminent threat for this population of blue whales [69]. However, since ship strike mortality exceeds legal limits in the United States and blue whales do not react to oncoming vessels this population remains vulnerable to ship collisions, particularly in areas of high ship traffic [56].

The overlap between shipping lanes off southern Sri Lanka and blue whale habitat is high [19]. Total mortality due to ship strike in this region is unknown, but during a 12-day period in 2012, two pygmy blue whales were struck and killed by vessels (one was draped across the bow of a container ship which entered Colombo Harbour (Figure 4), while the second was found at sea off the south coast with large propeller gashes), indicating potentially high mortality [70]. While these incidents represent clear evidence of ship strikes, confirmation of this nature is rare: it is often difficult 


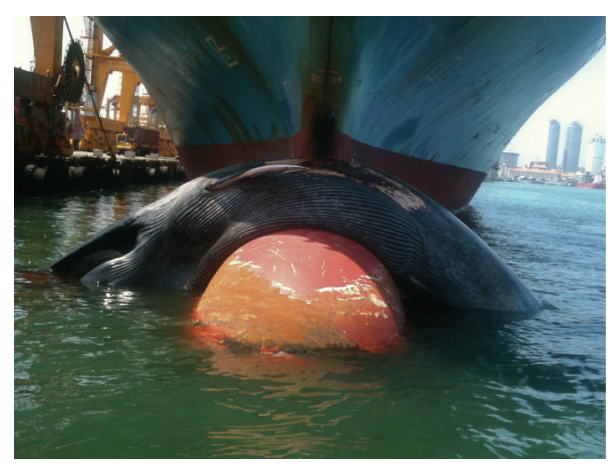

Figure 4: Blue whale on bow of container ship in Colombo Harbour, Sri Lanka, on the 20th of March 2012 (photo credit: Sopaka Karunasundara).

to ascertain the cause of death of decomposed beached carcasses, and it is likely that most struck individuals do not strand and sink offshore without being documented [71]. Williams et al. [72] estimated that actual vessel strike mortality to baleen whales could be as much as 10 times higher than observed, depending on location. Given this, it is likely that the events reported by de Vos et al. [70] are a fraction of actual ship strikes, which may be a significant cause of mortality to this population.

Tournadre [73] noted a dramatic fourfold increase in global ship traffic between the early 1990s and present, with largest growth in the Indian Ocean and Western Pacific Seas. Increases within this region reflect the redistribution of international trade and highlight the growing threat to pygmy blue whales within this region, particularly off Sri Lanka. Further, the construction of a new international port in Hambantota off the southeast coast, close to known pygmy blue whale foraging areas, is cause for concern. Thus, increased ship strikes could limit the recovery of this population, particularly given the projected global doubling of large vessel traffic in the next 10-20 years [74].

\subsection{Pollution}

3.3.1. Organochlorines. Sex-related differences in concentrations of PCBs and DDTs have been observed in fin whales from the eastern North Atlantic [75] and the Mediterranean Sea [76], right whales from the North Atlantic [77], and blue whales from the Gulf of St. Lawrence [78]. Further, studies in the Gulf of St. Lawrence on females and offspring of both blue and humpback whales showed that PCB congeners and organochlorines were present at the same levels in calves and females [78] demonstrating that these compounds are transferred across the placenta and during lactation as in some odontocetes [79]. Moreover, residue levels of persistent organochlorines (polychlorinated biphenyls, DDTs, and chlordane compounds, hexachlorocyclohexanes except hexachlorobenzene) were lower in minke whale blubber from the Antarctic than the North Pacific indicating both lower levels of these compounds in the Southern Hemisphere and the whale's lower trophic level feeding habits (only krill) within Antarctic waters [80].
A comprehensive review of the impacts of organochlorine contaminants showed no conclusive evidence for any impact on baleen whales [81]. Low levels of contaminants in baleen whales and especially blue whales relative to other marine mammals are related to diet and their location at or near the bottom of the food web.

3.3.2. Microplastics. Microplastics are small plastic particles in the environment generally $<5 \mathrm{~mm}$ in size [82]. Primary microplastics are those that are manufactured at microscopic size for use in facial cleansers and cosmetics [83] or as air-blasting media [84], while secondary microplastics form when larger plastic objects in the open ocean fragment continuously as a result of UV solar radiation and thermal/chemical degradation [85]. Cózar et al. [86] estimated that $88 \%$ of the ocean's surface contains microplastics. Due to their small size, microplastics are considered bioavailable to all marine organisms throughout the food web, and bioaccumulation in top predators is expected to occur as they incorporate microplastics and organic pollutants while feeding [87]. Filter feeders are particularly vulnerable to microlitter ingestion. While interactions between marine mammals and marine debris have been identified by Williams et al. [88] and Baulch and Perry [89] showed that 56\% of all stranded cetacean species had ingested marine debris (of which $46 \%$ were plastics of varying sizes), to date only one study has identified compounds (phthalates) in microplastics that may pose a threat to filter-feeding baleen whales [90]. The implications of this exposure are currently unknown [91].

3.3.3. Acoustic. Areas of high ship traffic are also associated with increased underwater noise. Low-frequency noise from large ships $(20-200 \mathrm{~Hz})$ overlaps with acoustic signals produced by communicating baleen whales, potentially resulting in "acoustic masking" [92, 93]. Baleen whales respond to elevated noise levels through changes in the intensity, frequency and interval of calls, behavioral changes, and habitat displacement $[94,95]$. Rorquals have been documented using low-frequency vocalizations for reproductive signaling; thus elevated anthropogenic noise has the potential to disrupt mating activity, impacting the reproductive success of individual whales and in turn having a population-level effect [96]. Moreover, Rolland et al. [97] showed that North Atlantic right whales showed signs of chronic stress when exposed to low-frequency underwater noise from ships.

The southern coast of Sri Lanka is an important blue whale feeding ground and lies immediately adjacent to one of the most heavily travelled shipping lanes in the world [65] (Figure 3). de Vos et al. [12] documented consistently high levels of shipping noise, particularly off the south coast of Sri Lanka. The impact of this noise on NIO pygmy blue whales especially any long-term cumulative impact is unknown; however, blue whales are known to predominantly call at frequencies similar to the dominant acoustic energy of ships [98]. Studies on blue whales off southern California show that in the presence of ships their calls are disrupted, particularly foraging-related D-call (distinct low-frequency $(<100 \mathrm{~Hz})$ sounds) production [99] with the amplitude of calls increased in closer proximity to ships $[99,100]$. McKenna et al. 
[100] found that blue whale B-calls, produced by males and potentially associated with mating, were not detectable when a commercial ship was within $4 \mathrm{~km}$ suggesting that, in the vicinity of a ship, blue whale communication distance was decreased.

3.3.4. Oil and Gas Development. Activities related to oil and gas exploration of concern to whales include potential mortality from increased ship traffic and oil spills as well as acoustic disturbance due to seismic surveying and drilling operations (e.g., [101]). Sri Lanka is presently in the initial stages of oil exploration, which will increase levels of geophysical seismic surveying and associated ship traffic. The main regions being explored around Sri Lanka lie within the Mannar Basin located at approximately $6^{\circ}-9^{\circ} \mathrm{N}$ and $78^{\circ}-80^{\circ} \mathrm{E}$ off the northwest coast [102]. Other areas of exploration have expanded to deep water off Sri Lanka's east and northeast coasts, all areas used by pygmy blue whales.

Seismic exploration in Sri Lanka is currently restricted to Sri Lanka's Mannar Basin and Cauvery Basin in the northwest [60] (Figure 3). Pygmy blue whales have been recorded in these waters adjacent to the Bar Reef Marine Sanctuary $[12,103]$. Studies on feeding western gray whales and feeding and migrating eastern gray whales indicate that some mysticetes avoid areas with seismic survey noise [104]. While published evidence for the effects of seismic activity on blue whales is limited, disruption of socially relevant signals could affect biologically important processes (e.g., mating) and have significant negative individual and population-level effects.

With the success of the exploration phases and gas discoveries in 2011, drilling operations off Sri Lanka are likely to increase [105]. The first production from Sri Lanka's gas fields is expected to occur by 2017/2018 in the waters off the northwest coast [105]. A precautionary approach with appropriate guidelines needs to be implemented to ensure minimal disruption to cetacean species using the area [106].

3.4. Whale-Watching. Ilangakoon [31] identified whalewatching as a cause for displacement of blue whales in 2011. However, de Vos et al. [19] showed that the temporary displacement of blue whales in 2011 from inshore waters was linked to La Niña-related excessive rainfall and flooding that year and that long-term increase in whale-watch boats did not drive shifts in the offshore distribution of whales. Therefore, it is not possible to conclude that the blue whales in 2011 were displaced due to whale-watching activities.

Senigaglia et al. [107] found no changes in the travelling speed or respiration rate of humpback whales (Megaptera novaeangliae) in relation to whale-watching activity off New Caledonia and Australia. Similarly, blue whales in Sri Lankan waters did not display behavioral changes in the presence of whale-watch boats [108]. Nevertheless there is public concern that persistent close approaches by tour boats may have a negative impact by disrupting the normal behavior patterns of whales [109]. In Sri Lankan waters, the main concern is with possible cumulative disruption of feeding activities resulting in below normal food intake. These threats are compounded by the currently unregulated and growing whale-watching industry.

3.5. Climate Change. The indirect effects of climate change on marine mammals include potential changes in the distribution, timing and range of migration, abundance of competitors, abundance of predators, availability of prey, timing of breeding, and reproductive success [110]. Temperature within the NIO is predicted to increase approximately $0.2^{\circ} \mathrm{C}$ per decade, driving a predicted rate of isotherm movement of $>200 \mathrm{~km} /$ decade [111]. It is unclear how these changes may affect the distribution and abundance of NIO blue whales, but the main concern focuses on how these changes in oceanographic conditions affect the density and distribution of their prey.

Short-term physical environmental changes are known to influence prey distributions which may drive interannual variability in blue whale distribution [19]. Similarly, longterm oceanographic changes resulting from climate change have the potential to cause permanent shifts in prey distributions, densities, and availability and ultimately their predators such as the blue whales that depend on them.

Research by Martinez-Levasseur et al. [112] documented UV exposure-induced mitochondrial DNA damage in seasonally sympatric blue, fin, and sperm whales that increased with age. The damage is counteracted through different mechanisms in each species depending on length of time at surface (and therefore sun exposure) and skin colouration. Given the increased level of solar UV radiation reaching the surface of the biosphere today this remains a potential threat to whales.

\section{Threat Analysis}

There are insufficient data to quantitatively rank the threats to NIO pygmy blue whales. Still we feel it is useful to attempt a prioritization of threats for this distinct, potentially small rorqual population. Therefore, we ranked the threats faced by blue whales using methods developed by Regan et al. [113] where threats were categorized based on their severity, scope, and immediacy (Table 1).

\section{Research Needs}

Further research can provide insight into the population trajectory and actions most likely to yield conservation benefits for this little known population of Northern Indian Ocean pygmy blue whales in Sri Lankan waters.

5.1. Population Size Estimation. It is difficult to evaluate and mitigate known and potential threats without estimates of abundance and information on population structure and trends. A study on blue and humpback whale abundance in the eastern North Pacific that compared abundance estimations calculated using line-transect and photoidentification techniques showed that nearshore aggregations of whales were easily and cost-effectively assessed using photo-identification techniques, while making it difficult to obtain effective samples in line-transect surveys covering 
TABLE 1: Prioritization of threats to Northern Indian Ocean pygmy blue whales in Sri Lankan waters (categories and descriptions based on Regan et al. [113]).

\begin{tabular}{|c|c|c|c|c|}
\hline Threat & Severity & Scope & Immediacy & Description \\
\hline Ship strike & High & Moderate & High & $\begin{array}{l}\text { Moderate-to-severe, imminent threat for a significant } \\
\text { proportion of population }\end{array}$ \\
\hline Incidental catch & Moderate & Low & High & Moderate threat for a small proportion of population \\
\hline $\begin{array}{l}\text { Oil and gas } \\
\text { development }\end{array}$ & Moderate & Low & High & Moderate threat for small proportion of population \\
\hline Pollution & Moderate & Low & High & Moderate threat for small proportion of population \\
\hline Whale-watching & Low & Low & High & $\begin{array}{l}\text { Low severity threat for a small proportion of population } \\
\text { (but rapidly increasing) }\end{array}$ \\
\hline Climate change & Low & Low & Moderate & $\begin{array}{l}\text { Low severity threat for a small proportion of population } \\
\text { but increasing }\end{array}$ \\
\hline Direct catch & Very low & Very low & Insignificant & Not a current threat \\
\hline
\end{tabular}

broader areas. However, populations of species that were distributed more broadly were more suited for line-transect surveys [114]. In Sri Lankan waters, blue whales form nearshore aggregations accessible from small boats and therefore photoidentification techniques are a cost-effective method to assess the population status.

The use of photographs to identify and resight individual whales is useful to estimate population size, delineate feeding stocks, and determine migration patterns $[115,116]$. A catalog of photographs of ventral tail flukes and left and right lateral sides of whales that are covered with clear and permanent mottling patterns unique to each individual [117] is maintained by The Sri Lankan Blue Whale Project with relevant metadata. While a work is in progress, the catalog presently holds 105 left dorsal photos, 98 right dorsal photos, 20 left and right dorsal photos, and 103 fluke photos with three between year matches.

5.2. Distribution of Blue Whales in relation to Vessel Traffic and Key Oil and Gas Exploration Areas and Seasonality. Aerial surveys, acoustic surveys, and prey modeling techniques can be used to address questions related to distribution, movement, and seasonality particularly in relation to large anthropogenic threats such as vessel traffic and oil and gas exploration. Identifying areas of high whale use in relation to ship traffic indicates areas of overlap and therefore highest risk [64]. This data can be used to model potential options for reducing overlap of shipping lanes and whales [64, 67].

Environmental impact assessments must be conducted prior to the commencement of oil and gas drilling and production. Based on the environmental impact assessment, guidelines and regulations that are considered necessary for a precautionary approach should be put in place for all future exploration, drilling, and production [106].

5.3. Determining Risk of Entanglement to the Population. Baleen whales are particularly susceptible to entanglement because they inhabit and migrate across continental shelf waters where $95 \%$ of fishing effort occurs [118]. Documenting incidents of entanglement through photographs enables us to determine the proportion of the population affected by this threat and to ascertain its overall impact. We also propose examining the distribution of fishing effort; particularly drift gill nets, in relation to blue whale distribution.

5.4. Determining Conservation Pressures through Assessment of Physiological Responses. Faecal samples have been used to assess stress levels in large whales, particularly endangered North Atlantic right whales [97, 119, 120]. Respiratory or "blow" samples provide physiologically relevant indicators of health and disease. Blow samples have been used to determine oestrogen and progesterone levels of individuals, cortisol levels, and microbiology. The results of these hormone analyses are important for determining population demographics, reproductive cycles, stress levels linked to anthropogenic activities, and immune status of large whales $[121,122]$. Blubber samples can be used to assess contaminant burdens of blue whales in the NIO. This has been successfully achieved for bowheads in Barrow, Alaska, and blue whales and humpback whales in the Gulf of St. Lawrence, Canada $[78,123]$. Photographic analyses allow the assessment of skin condition and nutritional status of individuals within a population.

Photographs can show detectable changes in body mass that may be related to nutritional status and provide information on skin conditions and other potential threats. The use of these nonlethal and noninvasive assessment methods can provide insight into the reproductive cycles, stress physiology, nutritional status, host immune response, pathogen, and parasite load of the NIO blue whales (for a comprehensive review on the methods available to study the conservation physiology of large whales, see [124]).

5.5. Strandings. The establishment of a well-managed islandwide stranding programme is an urgent need as strandings can provide a range of information otherwise unavailable to researchers. Strandings can be used to identify causes of death, especially ship strikes, and to obtain samples for DNA analyses and species identification in the event that a carcass is highly deteriorated. Further, hormones in baleen plates provide means to retrospectively assess stress or reproductive cycles and thereby reconstruct the life history of an individual whale. While still in its infancy, the technique has been 
successfully tested on bowhead whales (Balaena mysticetus) [125].

\section{Legal Protection}

Blue whales worldwide, including in the NIO, are protected by a commercial hunting moratorium established by the International Whaling Commission (IWC) and trade is not allowed under CITES (The Convention on International Trade in Endangered Species of Wild Flora and Fauna). Sri Lanka is also located in the Indian Ocean Sanctuary (area north of $55^{\circ} \mathrm{S}$ ) established by the IWC in 1979 [126], but this does not provide any additional protection for these whales. Furthermore, all cetaceans in Sri Lankan waters are protected under two laws: (1) the Fauna and Flora Protection Ordinance (Amendment) Act, number 22 of 2009, and (2) the Fisheries and Aquatic Resources Act, number 2 of 1996. While both acts consider injury, removal, and trade and the Sea Mammals (Observation, Regulation, and Control) Regulations, number 1 of 2012, outlines some regulations for maneuvering in the presence of marine mammals, none of them consider threats from vessel strike, entanglement and bycatch, oil and gas development, and pollution, all activities that pose potential threats to the whales in these waters. This highlights the need for proper implementation of existing legislation and further development in light of known and predicted threats.

\section{Conclusions}

Our review of the available limited evidence suggests that the most significant threat faced by this population is the heavy ship traffic that navigates off the south coast of Sri Lanka on a daily basis. These shipping lanes overlap with prime blue whale habitat and deaths by ship strike have been documented. Despite the large number of whales killed by Soviet whaling in the 1960s, indicating that their populations are likely low, the NIO blue whales have not been assessed independently by the IUCN [127]. Therefore, there is an urgent need to reduce any human-related mortality especially ship strikes as much as possible. It is also important to consider the cumulative pressures placed on this population by the significant number of human threats such as to whalewatching occurring in these nearshore waters. Ultimately, to better understand blue whale threats in Sri Lankan waters, research is needed to determine the size of the population, distribution in relation to shipping traffic and oil and gas exploration activities, ship strike, and entanglement risk and possible pollution-based threats.

\section{Competing Interests}

The authors declare that they have no competing interests.

\section{Acknowledgments}

This work was made possible by a grant from the Marisla Foundation (Grant no. 4-12-280). The authors wish to thank Tony Wu and Sopaka Karunasundara for providing images of entanglement and ship strike. Previous versions of the paper also benefitted greatly from input by anonymous reviewers. Fieldwork that informed some of this work and photos were taken under Permit no. WL/3/2/1/18 issued by the Department of Wildlife Conservation, Sri Lanka.

\section{References}

[1] V. A. Zemsky and E. G. Sazhinov, "Distribution and abundance of the pygmy blue whale," Translated by V. S. Gurevich, edited by M. A. Donahue and R. L. Brownell Jr., National Marine Fisheries Service, Southwest Fisheries Science Center, Administrative Report LJ-94-02, pp. 1-17, 1994.

[2] F. Samaran, K. M. Stafford, T. A. Branch et al., "Seasonal and geographic variation of southern blue whale subspecies in the Indian Ocean," PLoS ONE, vol. 8, no. 8, Article ID e71561, 2013.

[3] T. Ichihara, "The pygmy blue whale, Balaenoptera musculus brevicauda, a new subspecies from the Antarctic," in Whales, Dolphins and Porpoises, K. S. Norris, Ed., pp. 79-111, University of California Press, Berkeley, Calif, USA, 1966.

[4] S. Rennie, C. E. Hanson, R. D. McCauley et al., "Physical properties and processes in the Perth Canyon, Western Australia: links to water column production and seasonal pygmy blue whale abundance," Journal of Marine Systems, vol. 77, no. 1-2, pp. 2144, 2009.

[5] Cetacean Specialist Group, "Balaenoptera musculus ssp. brevicauda," 1996, http://dx.doi.org/10.2305/IUCN.UK.1996.RLTS .T2479A9449204.en.

[6] R. L. Jr. Brownell and M. A. Donahue, "Southern Hemisphere pelagic whaling for pygmy blue whales: review of catch statistics," Paper Presented to Scientific Committee of IWC, SC/46/SH6, 1994.

[7] SMM Committee on Taxonomy List of marine mammal species and subspecies, Society for Marine Mammalogy, 2016, https:// www.marinemammalscience.org/.

[8] Y. A. Mikhalev, "Whaling in the Arabian Sea by the whaling fleets Slava and Sovetskaya Ukraina," in Soviet Whaling Data (1949-1979), A. V. Yablokov and V. A. Zemsky, Eds., pp. 141181, Center for Russian Environmental Policy Marine Mammal Council, Moscow, Russia, 2000.

[9] A. K. Alling and R. Payne, "Songs of Indian Ocean blue whales, Balaenoptera musculus," Unpublished, 11 pages, 1987.

[10] M. A. McDonald, S. L. Mesnick, and J. A. Hildebrand, "Biogeographic characterization of blue whale song worldwide: using song to identify populations," Journal of Cetacean Research and Management, vol. 8, pp. 55-65, 2006.

[11] A. K. Alling, E. M. Dorsey, and J. C. D. Gordon, "Blue whales (Balaenoptera musculus) off the Northeast coast of Sri Lanka: distribution, feeding and individual identification," in Cetaceans and Cetacean Research in the Indian Ocean Sanctuary: Marine Mammal Technical Report 3, S. Leatherwood and G. P. Donovan, Eds., pp. 247-258, United Nations Environment Programme Oceans and Coastal Areas Programme Activity Centre, Nairobi, Kenya, 1991.

[12] A. de Vos, R. Clark, C. Johnson et al., "Cetacean sightings and acoustic detections in the offshore waters of Sri Lanka: MarchJune 2003," Journal of Cetacean Research and Management, vol. 12, no. 1, pp. 185-193, 2012.

[13] A. D. Ilangakoon, "Preliminary analysis of large whale strandings in Sri Lanka 1889-2004," Pakistan Journal of Oceanography, vol. 2, pp. 61-68, 2006. 
[14] T. A. Branch, K. M. Stafford, D. M. Palacios et al., "Past and present distribution, densities and movements of blue whales Balaenoptera musculus in the Southern Hemisphere and northern Indian Ocean," Mammal Review, vol. 37, no. 2, pp. 116175, 2007.

[15] V. V. Afsal, K. S. S. M. Yousuf, B. Anoop et al., "A note on cetacean distribution in the Indian EEZ and contiguous seas during 2003-07," Journal of Cetacean Research and Management, vol. 10, no. 3, pp. 209-215, 2008.

[16] J. A. Small and G. Small, "Cetacean observations from the Somali Democratic Republic, September 1985 through May 1987," in Cetaceans and Cetacean Research in the Indian Ocean Sanctuary: Marine Mammal Technical Report 3, S. Leatherwood and G. P. Donovan, Eds., pp. 179-210, United Nations Environment Programme Oceans and Coastal Areas Programme Activity Centre, Nairobi, Kenya, 1991.

[17] R. C. Anderson, "Observations of cetaceans in the Maldives, 1990-2002," Journal of Cetacean Research and Management, vol. 7, pp. 119-135, 2005.

[18] L. T. Ballance, R. C. Anderson, R. L. Pitman et al., "Cetacean sightings around the Republic of the Maldives, April 1998," Journal of Cetacean Research and Management, vol. 3, pp. 213218, April 1998.

[19] A. de Vos, C. B. Pattiaratchi, and R. G. Harcourt, "Interannual variability in blue whale distribution off Southern Sri Lanka between 2011 and 2012," Journal of Marine Science and Engineering, vol. 2, no. 3, pp. 534-550, 2014.

[20] P. H. D. H. de Silva, Colombo Museum 100 years 1877-1977 Souvenir, State Printing Corporation, Panaluwa, Sri Lanka, 2nd edition, 1977.

[21] P. E. P. Deraniyagala, "Some mystacetid whales from Ceylon," Spolia Zeylanica, vol. 25, pp. 61-63, 1948.

[22] R. Sears, T. Doniol-Valcroze, C. Berchock, P. J. Palsbøll, A. Bendlin, and C. Ramp, "Sex structure and male-male competition in blue whale trios from the North Atlantic or simply a 'ménage à trois,' in Proceedings of the 18th Biennal Conference on the Biology of Marine Mammals, Quebec, Canada, October 2009.

[23] D. A. Croll, B. R. Tershy, R. P. Hewitt et al., "An integrated approch to the foraging ecology of marine birds and mammals," Deep Sea Research Part II: Topical Studies in Oceanography, vol. 45, no. 7, pp. 1353-1371, 1998.

[24] P. C. Fiedler, S. B. Reilly, R. P. Hewitt et al., "Blue whale habitat and prey in the California Channel Islands," Deep-Sea Research Part II: Topical Studies in Oceanography, vol. 45, no. 8-9, pp. 1781-1801, 1998.

[25] T. A. Branch, C. Allison, Y. A. Mikhalev, D. D. Tormosov, and R. L. Brownell Jr., "Historical catch series for Antarctic and pygmy blue whales," Paper Presented to the Scientific Committee of the IWC SC/60/SH09, 2008.

[26] V. A. Zemsky, A. A. Berzin, Y. A. Mikhalev, and D. D. Tormosov, "Soviet Antarctic pelagic whaling after WWII: review of actual catch data," Reports of the International Whaling Commission, vol. 46, pp. 131-135, 1995.

[27] V. A. Zemsky, Y. A. Mikhalev, and A. A. Berzin, "Supplementary information about Soviet whaling in the Southern Hemisphere," Reports of the International Whaling Commission, vol. 46, pp. 131-138, 1996.

[28] Y. A. Mikhalev, "Pygmy blue whales of the Northern-Western Indian Ocean," Paper Presented to the Scientific Committee of the IWC SC/48/SH30, 1996.
[29] P. Wray and K. R. Martin, "Historical whaling records from the western Indian Ocean," Report to the International Whaling Commission no. 5, pp. 213-241, 1983.

[30] P. J. Clapham, S. B. Young, and R. L. Brownell Jr., "Baleen whales: conservation issues and the status of the most endangered populations," Mammal Review, vol. 29, no. 1, pp. 35-60, 1999.

[31] A. Ilangakoon, "Exploring anthropogenic activities that threaten endangered blue whales (Balaenoptera musculus) off Sri Lanka," Journal of Marine Animals and Their Ecology, vol. 5, pp. 3-7, 2012.

[32] A. D. Davidson, A. G. Boyer, H. Kim et al., "Drivers and hotspots of extinction risk in marine mammals," Proceedings of the National Academy of Sciences of the United States of America, vol. 109, no. 9, pp. 3395-3400, 2012.

[33] B. S. Halpern, S. Walbridge, K. A. Selkoe et al., "A global map of human impact on marine ecosystems," Science, vol. 319, no. 5865, pp. 948-952, 2008.

[34] E. Zavaleta, J. Pasari, J. Moore, D. Hernández, K. B. Suttle, and C. C. Wilmers, "Ecosystem responses to community disassembly," Annals of the New York Academy of Sciences, vol. 1162, pp. 311333, 2009.

[35] R. L. Lewison, L. B. Crowder, A. J. Read, and S. A. Freeman, "Understanding impacts of fisheries bycatch on marine megafauna," Trends in Ecology and Evolution, vol. 19, no. 11, pp. 598-604, 2004.

[36] R. R. Reeves, K. McClellan, and T. B. Werner, "Marine mammal bycatch in gillnet and other entangling net fisheries, 1990 to 2011," Endangered Species Research, vol. 20, no. 1, pp. 71-97, 2013.

[37] A. J. Read, P. Drinker, and S. Northridge, "Bycatch of marine mammals in U.S. and global fisheries," Conservation Biology, vol. 20, no. 1, pp. 163-169, 2006.

[38] COSEWIC, COSEWIC Assessment and Update Status Report on the Blue Whale Balaenoptera Musculus in Canada, Committee on the Status of Endangered Wildlife in Canada, Ottawa, Canada, 2002, http://www.sararegistry.gc.ca/virtual_sara/files/ cosewic/sr_blue_whale_e.pdf.

[39] J. E. Heyning and T. D. Lewis, "Entanglements of baleen whales in fishing gear off southern California," Report of the International Whaling Commission, vol. 40, pp. 427-431, 1990.

[40] J. V. Carretta, E. Oleson, D. W. Weller et al., U.S. Pacific Marine Mammal Stock Assessments: 2013, U.S. Department of Commerce, Washington, Wash, USA, 2014, http://www.nmfs.noaa .gov/pr/sars/species.htm.

[41] W. A. Shyamantha and L. Pálmason, The Effects of the Colour of the Mainline and Different Snood Attachments on the Catching Efficiency of Longline, The United Nations University, Reykjavík, Iceland, 2005, http://www.unuftp.is/static/fellows/document/ shyamantha05prf.pdf.

[42] P. H. D. H. de Silva, "Cetaceans (whales, dolphins and porpoises) recorded off Sri Lanka, India, from the Arabian sea and Gulf, Gulf of Aden and from the Red sea," Journal of the Bombay Natural History Society, vol. 84, pp. 505-525, 1987.

[43] S. Leatherwood and R. R. Reeves, "Marine mammal research and conservation in Sri Lanka 1985-1986," Marine Mammal Technical Report 1, 1989.

[44] A. Ilangakoon, Whales and Dolphins, Sri Lanka: A Guide to Cetaceans in the Waters around Sri Lanka, WHT Publications Ltd., Colombo, Sri Lanka, 2002.

[45] D. W. Laist, A. R. Knowlton, J. G. Mead, A. S. Collet, and M. Podesta, "Collisions between ships and whales," Marine Mammal Science, vol. 17, no. 1, pp. 35-75, 2001. 
[46] D. R. Herath, "Identification of a stranded whale by mitochondrial DNA analysis-www.DNA-surveillance program in action," Asian Fisheries Science, vol. 20, pp. 319-324, 2007.

[47] M. Berman-Kowalewski, F. M. D. Gulland, S. Wilkin et al., "Association between blue whale (Balaenoptera musculus) mortality and ship strikes along the California coast," Aquatic Mammals, vol. 36, no. 1, pp. 59-66, 2010.

[48] A. S. Jensen and G. K. Silber, "Large whale ship strike database," US Department of Commerce, National Oceanic and Atmospheric Administration (NOAA) NOAA Technical Memorandum, NMFS-OPR-25, pp. 1-37, 2004.

[49] D. N. Wiley, M. Thompson, R. M. Pace, and J. Levenson, "Modeling speed restrictions to mitigate lethal collisions between ships and whales in the Stellwagen Bank National Marine Sanctuary, USA," Biological Conservation, vol. 144, no. 9, pp. 2377-2381, 2011.

[50] H. M. Guzman, C. G. Gomez, C. A. Guevara, and L. Kleivane, "Potential vessel collisions with Southern Hemisphere humpback whales wintering off Pacific Panama," Marine Mammal Science, vol. 29, no. 4, pp. 629-642, 2013.

[51] A. S. M. Vanderlaan and C. T. Taggart, "Vessel collisions with whales: the probability of lethal injury based on vessel speed," Marine Mammal Science, vol. 23, no. 1, pp. 144-156, 2007.

[52] S. D. Kraus, M. W. Brown, H. Caswell et al., "North Atlantic right whales in crisis," Science, vol. 309, no. 5734, pp. 561-562, 2005.

[53] G. K. Silber, J. D. Adams, and C. J. Fonnesbeck, "Compliance with vessel speed restrictions to protect North Atlantic right whales," PeerJ, vol. 2, article e399, 2014.

[54] P. B. Conn and G. K. Silber, "Vessel speed restrictions reduce risk of collision-related mortality for North Atlantic right whales," Ecosphere, vol. 4, no. 4, article 43, 2013.

[55] D. W. Laist, A. R. Knowlton, and D. E. Pendleton, "Effectiveness of mandatory vessel speed limits for protecting North Atlantic right whales," Endangered Species Research, vol. 23, no. 2, pp. 133-147, 2014.

[56] M. F. McKenna, J. Calambokidis, E. M. Oleson, D. W. Laist, and J. A. Goldbogen, "Simultaneous tracking of blue whales and large ships demonstrates limited behavioral responses for avoiding collision," Endangered Species Research, vol. 27, no. 3, pp. 219-232, 2015.

[57] R. P. Hewitt and D. A. Demer, "The use of acoustic sampling to estimate the dispersion and abundance of euphausiids, with an emphasis on Antarctic krill, Euphausia superba," Fisheries Research, vol. 47, no. 2-3, pp. 215-229, 2000.

[58] J. A. Goldbogen, J. Calambokidis, E. Oleson et al., "Mechanics, hydrodynamics and energetics of blue whale lunge feeding: efficiency dependence on krill density," Journal of Experimental Biology, vol. 214, no. 1, pp. 131-146, 2011.

[59] J. Potemra, PacIOOS, U.S. Integrated Ocean Observing System $\left(\right.$ IOOS $\left.^{\circledR}\right)$, National Oceanic and Atmospheric Administration (NOAA) Award \#NA11NOS0120039, 2012, http://www.pacioos.org.

[60] National Aquatic Resources Research and Development Agency, Initial environmental examination report: Three dimensional seismic survey for oil exploration in blue SL-200701-001 in Gulf of Mannar, Sri Lanka; Colombo 2009.

[61] L. T. Ballance and R. L. Pitman, "Cetaceans of the western tropical Indian Ocean: distribution, relative abundance, and comparisons with cetacean communities of two other tropical ecosystems," Marine Mammal Science, vol. 14, no. 3, pp. 429459, 1998.
[62] J. Calambokidis, "Blue whales off California," Whalewatcher, vol. 29, pp. 3-7, 1995.

[63] R. L. Brownell Jr., E. Cabrera, and B. G. Vernazzani, "Dead blue whale in Puerto Montt, Chile: another case of ship collision mortality," Paper Presented to the Scientific Committee of the IWC SC/65b/HIM08, 2014.

[64] L. M. Irvine, B. R. Mate, M. H. Winsor et al., "Spatial and temporal occurrence of blue whales off the U.S. West Coast, with implications for management," PLoS ONE, vol. 9, no. 7, article e102959, 2014.

[65] P. Kaluza, A. Kölzsch, M. T. Gastner, and B. Blasius, "The complex network of global cargo ship movements," Journal of the Royal Society Interface, vol. 7, no. 48, pp. 1093-1103, 2010.

[66] G. Eiden and T. Martinsen, "Maritime traffic density-results of PASTA MARE project. Preparatory Action for Assessment of the Capacity of Spaceborne Automatic Identification System Receivers to Support EU Maritime Policy," Technical Note 4.1 Vessel Density Mapping, 2010.

[67] J. V. Redfern, M. F. McKenna, T. J. Moore et al., "Assessing the risk of ships striking large whales in marine spatial planning," Conservation Biology, vol. 27, no. 2, pp. 292-302, 2013.

[68] A. Dettmer and C. Teufel, Reducing Ship Strikes to Whales, California Coastal Commission, 2014, http://montereybay.noaa .gov/resourcepro/resmanissues/pdf/140905ccc_shipstrikememo .pdf.

[69] C. C. Monnahan, T. A. Branch, and A. E. Punt, "Do ship strikes threaten the recovery of endangered eastern North Pacific blue whales?" Marine Mammal Science, vol. 31, no. 1, pp. 279-297, 2015.

[70] A. de Vos, T. Wu, and R. L. Brownell Jr., "Recent blue whale deaths due to ship strike around Sri Lanka," Paper Presented to Scientific Committee of the IWC SC/65a/HIM03, 2013.

[71] P. A. Allison, C. R. Smith, H. Kukert, J. W. Deming, and B. A. Bennett, "Deep-water taphonomy of vertebrate carcasses: a whale skeleton in the bathyal Santa Catalina Basin," Paleobiology, vol. 17, no. 1, pp. 78-89, 1991.

[72] R. Williams, S. Gero, L. Bejder et al., "Underestimating the damage: interpreting cetacean carcass recoveries in the context of the Deepwater Horizon/BP incident," Conservation Letters, vol. 4, no. 3, pp. 228-233, 2011.

[73] J. Tournadre, "Anthropogenic pressure on the open ocean: the growth of ship traffic revealed by altimeter data analysis," Geophysical Research Letters, vol. 41, no. 22, pp. 7924-7932, 2014.

[74] B. L. Southall, Shipping Noise and Marine Mammals: A Forum for Science, Management and Technology, National Oceanic and Atmospheric Administration, Arlington, Va, USA, 2005.

[75] A. Aguilar and A. Borrell, "Age- and sex-related changes in organochlorine compound concentrations in fin whales (Balaenopterus physalus)," Journal of Mammalogy, vol. 71, pp. 544$554,1988$.

[76] L. Marsili and S. Focardi, "Organochlorine levels in subcutaneous blubber biopsies of fin whales (Balaenoptera physalus) and striped dolphins (Stenella coeruleoalba) from the Mediterranean Sea," Environmental Pollution, vol. 91, no. 1, pp. 1-9, 1996.

[77] A. V. Weisbrod, D. Shea, M. J. Moore, and J. J. Stegeman, "Organochlorine exposure and bioaccumulation in the endangered Northwest Atlantic right whale (Eubalaena glacialis) population," Environmental Toxicology and Chemistry, vol. 19, no. 3, pp. 654-666, 2000.

[78] C. Metcalfe, B. Koenig, T. Metcalfe, G. Paterson, and R. Sears, "Intra- and inter-species differences in persistent organic contaminants in the blubber of blue whales and humpback whales 
from the Gulf of St. Lawrence, Canada," Marine Environmental Research, vol. 57, no. 4, pp. 245-260, 2004.

[79] J. M. Gauthier, É. Pelletier, C. Brochu, S. Moore, C. D. Metcalfe, and P. Béland, "Environmental contaminants in tissues of a neonate St Lawrence beluga whale (Delphinapterus leucas)," Marine Pollution Bulletin, vol. 36, no. 1, pp. 102-108, 1998.

[80] S. Aono, S. Tanabe, Y. Fujise, H. Kato, and R. Tatsukawa, "Persistent organochlorines in minke whale (Balaenoptera acutorostrata) and their prey species from the Antarctic and the North Pacific," Environmental Pollution, vol. 98, no. 1, pp. 81-89, 1997.

[81] T. J. O’Shea and R. L. Brownell Jr., "Organochlorine and metal contaminants in baleen whales: a review and evaluation of conservation implications," Science of the Total Environment, vol. 154, no. 2-3, pp. 179-200, 1994.

[82] A. L. Andrady, "Microplastics in the marine environment," Marine Pollution Bulletin, vol. 62, no. 8, pp. 1596-1605, 2011.

[83] L. S. Fendall and M. A. Sewell, "Contributing to marine pollution by washing your face: microplastics in facial cleansers," Marine Pollution Bulletin, vol. 58, no. 8, pp. 1225-1228, 2009.

[84] M. R. Gregory, "Plastic 'scrubbers' in hand cleansers: a further (and minor) source for marine pollution identified," Marine Pollution Bulletin, vol. 32, no. 12, pp. 867-871, 1996.

[85] J. A. Ivar Do Sul and M. F. Costa, "The present and future of microplastic pollution in the marine environment," Environmental Pollution, vol. 185, pp. 352-364, 2014.

[86] A. Cózar, F. Echevarría, J. I. González-Gordillo et al., "Plastic debris in the open ocean," Proceedings of the National Academy of Sciences of the United States of America, vol. 111, no. 28, pp. 10239-10244, 2014.

[87] M. Oliveira, A. Ribeiro, and L. Guilhermino, "Effects of exposure to microplastics and PAHs on microalgae Rhodomonas baltica and Tetraselmis chuii," Comparative Biochemistry and Physiology Part A: Molecular \& Integrative Physiology, vol. 163, supplement, pp. S19-S20, 2012.

[88] R. Williams, E. Ashe, and P. D. O'Hara, "Marine mammals and debris in coastal waters of British Columbia, Canada," Marine Pollution Bulletin, vol. 62, no. 6, pp. 1303-1316, 2011.

[89] S. Baulch and C. Perry, "Evaluating the impacts of marine debris on cetaceans," Marine Pollution Bulletin, vol. 80, no. 1-2, pp. 210221, 2014.

[90] M. C. Fossi, C. Panti, C. Guerranti et al., "Are baleen whales exposed to the threat of microplastics? A case study of the Mediterranean fin whale (Balaenoptera physalus)," Marine Pollution Bulletin, vol. 64, no. 11, pp. 2374-2379, 2012.

[91] A. Hall and J. Kershaw, "Review of microplastics in the marine environment and their potential for impacts on cetaceans," in Proceedings of the Meeting of the IWC Scientific Committee (IWC '14), 2014, SC/65b/E13.

[92] National Research Council, Ocean Noise and Marine Mammals, The National Academies Press, Washington, DC, USA, 2003.

[93] C. W. Clark, W. T. Ellison, B. L. Southall et al., "Acoustic masking in marine ecosystems: intuitions, analysis, and implication," Marine Ecology Progress Series, vol. 395, pp. 201-222, 2009.

[94] D. P. Nowacek, L. H. Thorne, D. W. Johnston, and P. L. Tyack, "Responses of cetaceans to anthropogenic noise," Mammal Review, vol. 37, no. 2, pp. 81-115, 2007.

[95] L. S. Weilgart, "The impacts of anthropogenic ocean noise on cetaceans and implications for management," Canadian Journal of Zoology, vol. 85, no. 11, pp. 1091-1116, 2007.
[96] D. A. Croll, C. W. Clark, J. Calambokidis, W. T. Ellison, and B. R. Tershy, "Effect of anthropogenic low-frequency noise on the foraging ecology of Balaenoptera whales," Animal Conservation, vol. 4, no. 1, pp. 13-27, 2001.

[97] R. M. Rolland, S. E. Parks, K. E. Hunt et al., "Evidence that ship noise increases stress in right whales," Proceedings of the Royal Society B: Biological Sciences, vol. 279, no. 1737, pp. 2363-2368, 2012.

[98] W. J. Richardson, J. C. R. Greene, C. I. Malme, and D. H. Thomson, Marine Mammals and Noise, Academic Press, New York, NY, USA, 1995.

[99] M. L. Melcón, A. J. Cummins, S. M. Kerosky, L. K. Roche, S. M. Wiggins, and J. A. Hildebrand, "Blue whales respond to anthropogenic noise," PLoS ONE, vol. 7, no. 2, Article ID e32681, 2012.

[100] M. F. McKenna, M. S. Soldevilla, E. M. Oleson, S. Wiggins, and J. A. Hildebrand, "Increased underwater noise levels in the Santa Barbara channel from commercial ship traffic and the potential impact on blue whales (Balaenoptera musculus)," in Proceedings of the 7th California Islands Symposium, C. C. Damiani and D. K. Garcelon, Eds., Institute for Wildlife Studies, Arcata, Calif, USA, 2009.

[101] S. E. Moore and J. T. Clarke, "Potential impact of offshore human activities on gray whales (Eschrichtius robustus)," Journal of Cetacean Research and Management, vol. 4, pp. 19-25, 2002.

[102] R. Sorkhabi, "Cairn discovers gas offshore Sri Lanka," GEO ExPro, vol. 9, pp. 100-101, 2013.

[103] A. D. Ilangakoon, "Cetacean occurrence and distribution around the bar reef marine sanctuary, North-West Sri Lanka," Journal of the National Science Foundation of Sri Lanka, vol. 34, no. 3, pp. 149-154, 2006.

[104] D. W. Weller, S. H. Richards, A. L. Bradford, A. M. Burdin, and R. L. Brownell Jr., "The influence of 1997 seismic surveys on the behaviour of western gray whales off Sakhalin Island, Russia," Paper presented to Scientific Committee of the IWC SC/58/E4, 2006.

[105] C. C. Yew, Sri Lanka Takes Steps to Develop Petroleum Industry, Rigzone, 2014, http://www.rigzone.com/news/oil_gas/a/133735/ Sri_Lanka_Takes_Steps_to_Develop_Petroleum_Industry.

[106] D. P. Nowacek, K. Bröker, G. Donovan et al., "Responsible practices for minimizing and monitoring environmental impacts of marine seismic surveys with an emphasis on marine mammals," Aquatic Mammals, vol. 39, no. 4, pp. 356-377, 2013.

[107] V. Senigaglia, L. Bejder, F. Christiansen et al., "Meta-analasyes of whalewatching impact studies: differences and similarities in disturbance responses among species," Paper Presented to the IWC Scientific Committee SC/64/WW6, 2012.

[108] A. de Vos, F. Christiansen, R. G. Harcourt, and C. B. Pattiaratchi, "Surfacing characteristics and diving behaviour of blue whales in Sri Lankan waters," Journal of Experimental Marine Biology and Ecology, vol. 449, pp. 149-153, 2013.

[109] D. Cressey, "Ecotourism rise hits whales," Nature, vol. 512, no. 7515, p. 358, 2014.

[110] J. A. Learmonth, C. D. Macleod, M. B. Santos, G. J. Pierce, H. Q. P. Crick, and R. A. Robinson, "Potential effects of climate change on marine mammals," Oceanography and Marine Biology, vol. 44, pp. 431-464, 2006.

[111] M. T. Burrows, D. S. Schoeman, L. B. Buckley et al., "The pace of shifting climate in marine and terrestrial ecosystems," Science, vol. 334, no. 6056, pp. 652-655, 2011. 
[112] L. M. Martinez-Levasseur, M. A. Birch-Machin, A. Bowman et al., "Whales use distinct strategies to counteract solar ultraviolet radiation," Scientific Reports, vol. 3, article 2386, 2013.

[113] T. J. Regan, L. L. Master, and G. A. Hammerson, "Capturing expert knowledge for threatened species assessments: a case study using NatureServe conservation status ranks," Acta Oecologica, vol. 26, no. 2, pp. 95-107, 2004.

[114] J. Calambokidis and J. Barlow, "Abundance of blue and humpback whales in the eastern north pacific estimated by capturerecapture and line-transect methods," Marine Mammal Science, vol. 20, no. 1, pp. 63-85, 2004.

[115] S. Dufault and H. Whitehead, "Regional and group-level differences in fluke markings and notches of sperm whales," Journal of Mammalogy, vol. 79, no. 2, pp. 514-520, 1998.

[116] J. Calambokidis, G. H. Steiger, J. M. Straley et al., "Movements and population structure of humpback whales in the North Pacific," Marine Mammal Science, vol. 17, no. 4, pp. 769-794, 2001.

[117] R. Sears, J. M. Williamson, F. W. Wenzel, M. Bérubé, D. Gendron, and P. Jones, "Photographic identification of the blue whale (Balaenoptera musculus) in the Gulf of St. Lawrence, Canada," Report to the International Whaling Commission no. 12, pp. 335-342, 1990.

[118] D. Pauly, "Beyond duplicity and ignorance in global fisheries," Scientia Marina, vol. 73, no. 2, pp. 215-224, 2009.

[119] R. M. Rolland, K. E. Hunt, S. D. Kraus, and S. K. Wasser, "Assessing reproductive status of right whales (Eubalaena glacialis) using fecal hormone metabolites," General and Comparative Endocrinology, vol. 142, no. 3, pp. 308-317, 2005.

[120] K. L. Ayres, R. K. Booth, J. A. Hempelmann et al., "Distinguishing the impacts of inadequate prey and vessel traffic on an endangered killer whale (Orcinus orca) population," PLoS ONE, vol. 7, no. 6, Article ID e36842, 2012.

[121] C. J. Hogg, T. L. Rogers, A. Shorter, K. Barton, P. J. O. Miller, and D. Nowacek, "Determination of steroid hormones in whale blow: it is possible," Marine Mammal Science, vol. 25, no. 3, pp. 605-618, 2009.

[122] J. Dunstan, A. Gledhell, A. Hall, P. Miller, and C. Ramp, Quantification of the Hormones Progesterone and Cortisol in Whale Breath Samples Using Novel, Non-Invasive Sampling and Analysis with Highly-Sensitive ACQUITY UPLC and Xevo TQ$S$, Waters Application Note: Waters Corporation, Milford, Mass, USA, 2012.

[123] P. F. Hoekstra, T. M. O’Hara, S. J. Pallant, K. R. Solomon, and D. C. G. Muir, "Bioaccumulation of organochlorine contaminants in bowhead whales (Balaena mysticetus) from Barrow, Alaska," Archives of Environmental Contamination and Toxicology, vol. 42, no. 4, pp. 497-507, 2002.

[124] K. E. Hunt, M. J. Moore, R. M. Rolland et al., "Overcoming the challenges of studying conservation physiology in large whales: a review of available methods," Conservation Physiology, vol. 1, no. 1, Article ID cot006, 2013.

[125] K. E. Hunt, R. Stimmelmayr, C. George et al., "Baleen hormones: a novel tool for retrospective assessment of stress and reproduction in bowhead whales (Balaena mysticetus)," Conservation Physiology, vol. 2, no. 1, Article ID cou030, 2014.

[126] S. Leatherwood and G. P. Donovan, "Cetaceans and cetacean research in the Indian Ocean Sanctuary," Marine Mammal Technical Report 3, United Nations Environment Programme Oceans and Coastal Areas Programme Activity Centre, Nairobi, Kenya, 1991.
[127] S. B. Reilly, J. L. Bannister, P. B. Best et al., "Balaenoptera musculus," The IUCN Red List of Threatened Species 2008: e.T2477A9447146, 2008, Downloaded on 24 June 2016, http://dx .doi.org/10.2305/IUCN.UK.2008.RLTS.T2477A9447146.en. 

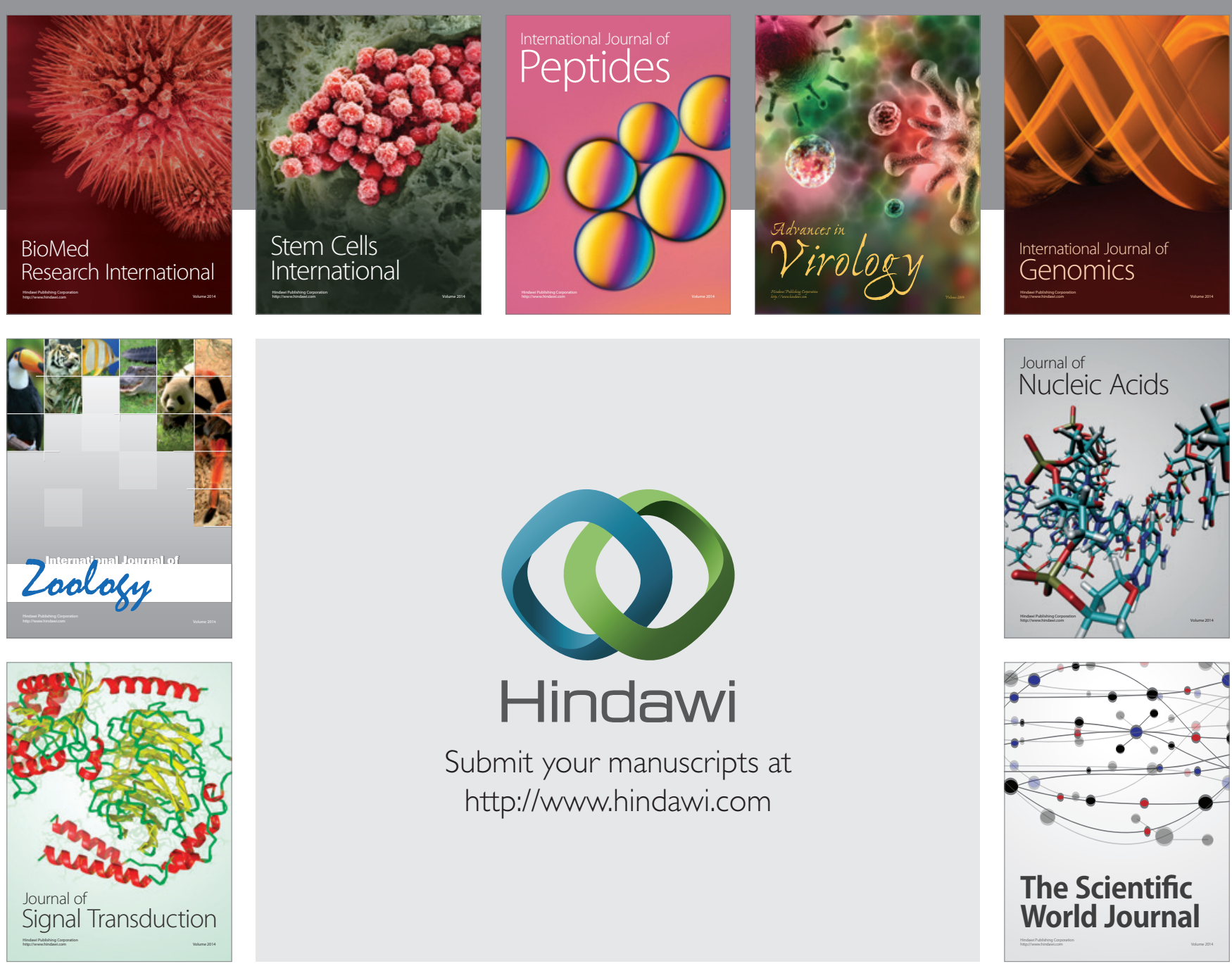

Submit your manuscripts at

http://www.hindawi.com
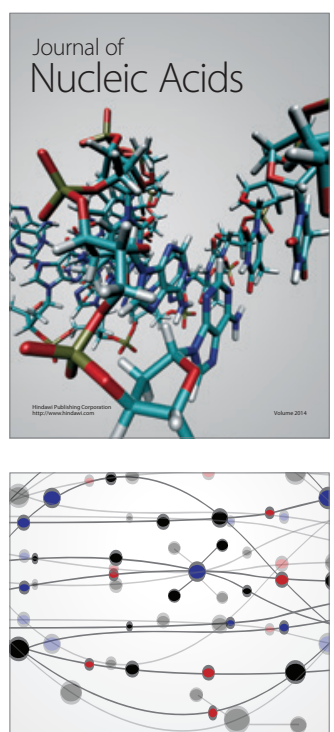

The Scientific World Journal
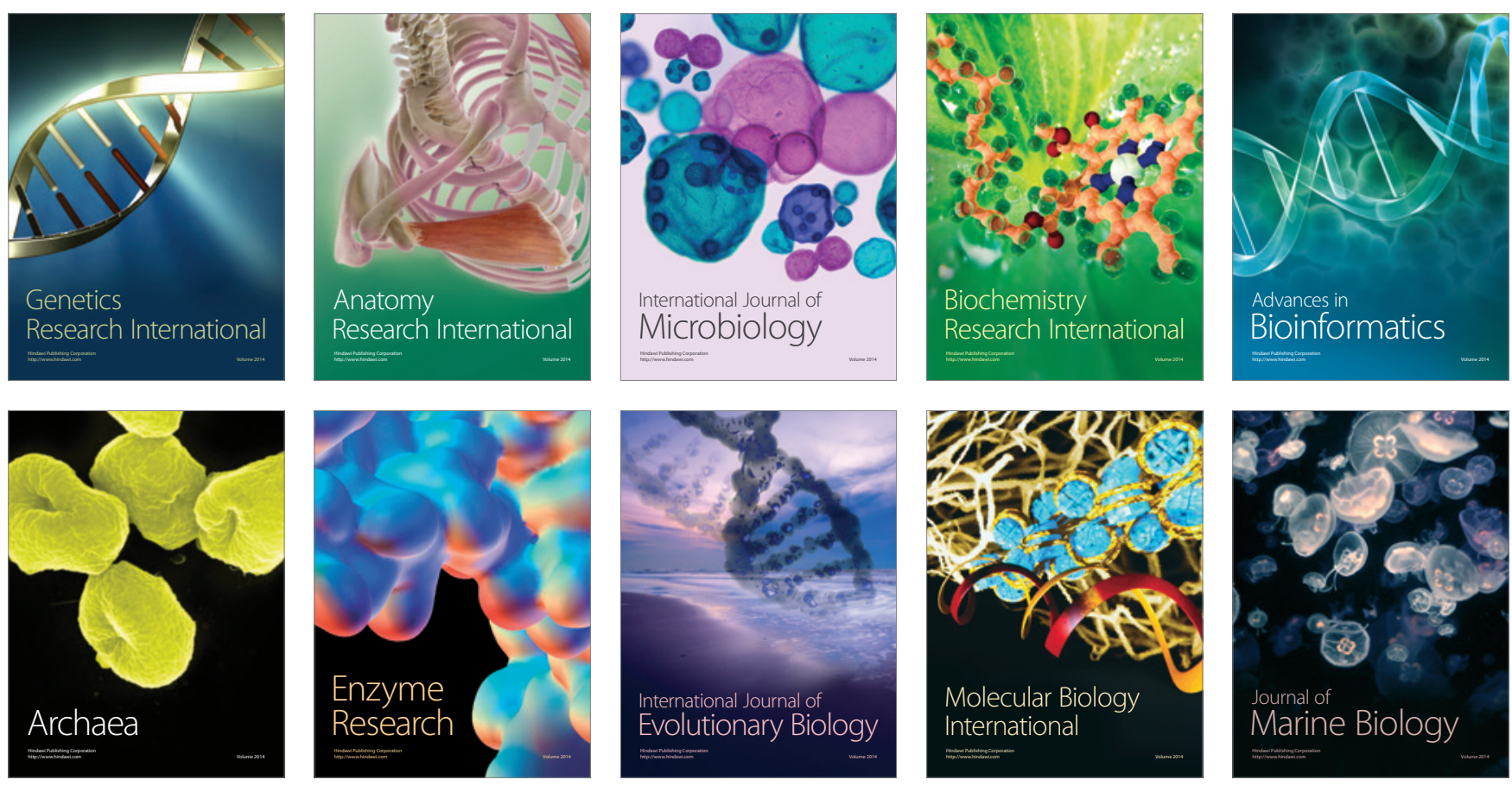